\title{
PROFILOWANIE BEZROBOTNYCH - PROBLEMY I WYZWANIA
}

\section{Wprowadzenie}

Bezrobocie w Polsce jako problem społeczny i ekonomiczny pojawiło się po odzyskaniu przez Polskę niepodległości w trzech różnych okresach ${ }^{1}$, tj. w latach: 1918-1939², 1944-19893 oraz na przełomie lat 80 . i $90 .{ }^{4}$ poprzedniego wieku. W ostatnim wymienionym okresie transformacja polskiej gospodarki spowodowała dotkliwe zmiany w różnych obszarach życia społeczeństwa - szczególnie w sferze zatrudnienia i rynku pracy. Zamykanie przedsiębiorstw, masowe zwalnianie pracowników doprowadziło do kilkunastoprocentowego bezrobocia w Polsce ${ }^{5}$. Powolny jego spadek rozpoczął się dopiero po wejściu Polski do Unii Europejskiej w 2004 r. Z otwarciem granic pojawiła się możliwość dla Polaków podjęcia pracy na terenie Unii Europejskiej. Wówczas bezrobocie obniżyło się z 19,5\% w maju 2004 r. się do 8,8\% w październiku 2008 r.

Kryzys gospodarczy na świecie w $2008 \mathrm{r}$. odbił się echem także u polskich pracodawców, którzy ograniczając koszty związane z zatrudnieniem, zwalniali pracowników. W ten sposób stopa bezrobocia ponownie zaczęła rosnąć z 8,9\% na koniec września 2008 r. ${ }^{6}$ do 9,6\% na koniec października 2015 r. ${ }^{7}$ Według danych Eurostatu

\footnotetext{
1 K. Mlonek, Bezrobocie w Polsce w XX wieku w świetle badań, Wydawnictwo i Zakład Poligrafii Instytutu Technologii Eksploatacji, Warszawa 1999, s. 5.

2 W latach II Rzeczypospolitej Polskiej, od chwili odzyskania niepodległości do ponownej jej utraty spowodowanej II wojną światową, bezrobocie było stałym elementem rzeczywistości społeczno-gospodarczej. Brak pracy nękał kilkutysięczną rzeszę bezrobotnych w miastach oraz w postaci utajonej kilkumilionową masę zbędnych na wsi.

3 To okres Polskiej Rzeczypospolitej Ludowej - konstytucyjne gwarancje prawa do pracy oraz realizowana polityka pełnego zatrudnienia doprowadziły do likwidacji jawnego bezrobocia w skali globalnej, ale jednocześnie przyczyniły się do wysokiego bezrobocia ukrytego, któremu okresowo towarzyszyły tzw. lokalne nadwyżki siły roboczej.

4 Lata odrodzonej w 1989 r. III Rzeczypospolitej Polskiej.

5 Od 10,5\% w październiku 1991 r. do 20,6\% w marcu 2003 r., według danych GUS.

6 Początek kryzysu gospodarczego w Stanach Zjednoczonych.

7 www.stat.gov.pl - GUS, bezrobocie rejestrowane w październiku $2015 \mathrm{r}$.
} 
we wrześniu 2015 r. stopa bezrobocia w strefie euro wyniosła 10,8\%. Najwyższe bezrobocie odnotowano w Hiszpanii - 21,6\%, a najniższe w Niemczech - 4,5\%.

Podobnie jak wiele krajów UE Polska musi podjąć wysiłek sprostania wyzwaniom rynku pracy dzięki zmianom w polityce zatrudnienia i w prawie pracy. Zdaniem E. Kryńskiej konieczna jest „weryfikacja metod instrumentów oddziaływania, wdrażanie mechanizmów pomiarów efektywności i wprowadzanie programów szerszego stosowania współpracy publicznych służb zatrudnienia z prywatnymi agencjami zatrudnienia, pracodawcami, a także ze związkami zawodowymi”.

Celem artykułu jest pokazanie, jakie problemy wynikają z faktu rejestracji i ustalenia profilu pomocy dla bezrobotnego. Szczególna uwaga zwrócona zostanie na ustawową definicję bezrobotnego, jego rejestrację, profilowanie, aż po pomoc, która przysługuje mu w tym zakresie. Jednocześnie wskazane zostaną zalety i wady profilowania pomocy, które wprowadzone zostało w maju 2014 r. w Polsce.

\section{Pojęcie bezrobocia}

W literaturze przedmiotu znajdziemy wiele definicji bezrobotnego prezentowanych np. przez Johna Maynarda Keynesa ${ }^{9}$, Mieczysława Kabaja ${ }^{10}$, Eugeniusza Kwiatkowskiego ${ }^{11}$ czy Elżbietę Kryńską ${ }^{12}$. W niniejszym opracowaniu przyjęto pojęcie bezrobotnego zawarte w art. 2 pkt 2 Ustawy z dnia 20 kwietnia 2004 r. o promocji zatrudnienia

8 E. Kryńska, Dylematy polskiego rynku pracy, IPiSS, Warszawa 2001, s. 37.

9 Angielski ekonomista John Maynard Keynes twierdził, że bezrobocie nie ma charakteru dobrowolnego, lecz przymusowy i jest skutkiem niedostatecznego popytu. Jego definicja brzmi następująco: „Ludzie są bezrobotni nie z własnej woli, jeżeli - w wypadku niewielkiej zwyżki cen artykułów konsumpcji robotniczej w porównaniu z płacą nominalną - zarówno łączna podaż siły roboczej gotowej do podjęcia pracy za wynagrodzenie według bieżących stawek płac nominalnych, jak i łączny popyt na nią przy tych stawkach byłyby większe od istniejącego poziomu zatrudnienia”. J.M. Keynes, Ogólna teoria zatrudnienia, procentu i pieniądza, Wydawnictwo Naukowe PWN, Warszawa 2003, s. 16.

${ }_{10}$ Mieczysław Kabaj określa, że „bezrobocie przeważnie oznacza bezczynność, oderwanie się od środowiska pracy, radykalną zmianę trybu życia. Bezrobotny odzwyczaja się od normalnego trybu życia: praca, dyscyplina, rytm, czas wolny; zrywa wszelkie więzi ze środowiskiem pracy”. M. Kabaj, Program przeciwdziałania ubóstwu i bezrobociu, IPiSS, Warszawa 2000, s. 84.

11 Eugeniusz Kwiatkowski definiuje „bezrobocie jako zjawisko braku pracy zarobkowej wśród osób będących w pewnym przedziale wiekowym, które są zdolne i gotowe do pracy oraz pracy tej poszukują”. E. Kwiatkowski, Bezrobocie, Podstawy teoretyczne, Wydawnictwo Naukowe PWN, Warszawa 2002, s. 20.

12 Elżbieta Kryńska konstatuje, że źródeł bezrobocia upatruje się, w zależności od przyjętego modelu przeciwdziałania bezrobociu: „W małej aktywności osób bezrobotnych oraz niesprawnym funkcjonowaniu urzędów pracy - w przypadku modeli, które skupiają się na środowiskach i programach aktywnej polityki rynku pracy, bądź też w deficycie miejsc pracy - w przypadku modeli, które koncentrują się na zintegrowanej, prozatrudnieniowej polityce społeczno-gospodarczej”. E. Kryńska, op.cit., s. 37. 
i instytucjach rynku pracy. Ustawodawca wskazuje w nim, jakie przesłanki należy spełnić, żeby otrzymać status osoby bezrobotnej. Jest to osoba, która m.in.:

„1) bezpośrednio przed rejestracją jako osoba bezrobotna była zatrudniona nieprzerwanie na terytorium Rzeczypospolitej Polskiej przez okres co najmniej 6 miesięcy;

2) jest niezatrudniona, niewykonująca innej pracy zarobkowej, zdolna i gotowa do podjęcia zatrudnienia w pełnym wymiarze czasu pracy obowiązującym w danym zawodzie lub w danej służbie albo innej pracy zarobkowej, a jeżeli jest osobą niepełnosprawną, zdolną i gotową do podjęcia zatrudnienia co najmniej w połowie tego wymiaru czasu pracy, nieuczącą się w szkole, z wyjątkiem uczącej się w szkole dla dorosłych lub przystępującej do egzaminu eksternistycznego z zakresu programu nauczania tej szkoły lub w szkole wyższej, gdzie studiuje na studiach niestacjonarnych, zarejestrowaną we właściwym dla miejsca zameldowania stałego lub czasowego powiatowym urzędzie pracy oraz poszukującą zatrudnienia lub innej pracy zarobkowej, jeżeli m.in:

- ukończyła 18 lat,

- nie osiągnęła wieku emerytalnego,

- nie nabyła prawa m.in. do: emerytury, renty, zasiłku przedemerytalnego, świadczenia rehabilitacyjnego, zasiłku chorobowego, macierzyńskiego,

- nie jest posiadaczem samoistnym lub zależnym nieruchomości rolnej,

- nie złożyła wniosku o wpis do ewidencji działalności gospodarczej,

- nie jest osobą tymczasowo aresztowaną lub odbywającą karę pozbawienia wolności,

- nie uzyskuje miesięcznych przychodów w wysokości przekraczającej połowę minimalnego wynagrodzenia za pracę,

- nie podlega, na podstawie odrębnych przepisów, obowiązkowi ubezpieczenia społecznego, z wyjątkiem ubezpieczenia rolników,

- nie pobiera na podstawie przepisów o ustaleniu i wypłacie zasiłków dla opiekunów zasiłku dla opiekuna"13.

Uwzględniając powyższe przesłanki, osoba pozostająca bez pracy może zarejestrować się w powiatowym urzędzie pracy.

${ }^{13}$ Art. 2 pkt 2 Ustawy z dnia 20 kwietnia 2004 r. o promocji zatrudnienia i instytucjach rynku pracy, DzU 2004 nr 99, poz. 1001. 


\section{Rejestracja bezrobotnych}

Osoba, która z różnych przyczyn nie świadczy pracy zarobkowej, może zarejestrować się jako osoba bezrobotna w powiatowym urzędzie pracy właściwym dla miejsca zameldowania.

Zgodnie z obowiązującym prawem osoba chcąca zarejestrować się jako bezrobotna, może to uczynić w następujący sposób ${ }^{14}$ :

1) powinna zgłosić się do powiatowego urzędu pracy, właściwego ze względu na miejsce zameldowania stałego lub czasowego, a jeżeli nie jest zameldowana - do powiatowego urzędu pracy, na którego obszarze działania przebywa, zwanego dalej „właściwym powiatowym urzędem pracy”, albo

2) wypełnić wniosek o dokonanie rejestracji za pośrednictwem formularza elektronicznego, dostępnego na stronie internetowej ministra właściwego do spraw pracy lub w Biuletynie Informacji Publicznej ministra właściwego do spraw pracy lub za pośrednictwem elektronicznej platformy usług administracji publicznej, o której mowa w Ustawie z dnia 17 lutego 2005 r. o informatyzacji działalności podmiotów realizujących zadania publiczne ${ }^{15}$.

Rejestracja bezrobotnego następuje w dniu przedłożenia kompletu dokumentów ${ }^{16}$, które są poświadczane przez bezrobotnego własnoręcznym podpisem. Dokonanie rejestracji nie jest niekiedy łatwe, ponieważ ilość dokumentów potrzebnych do rejestracji jest spora. Powiatowy urząd pracy może wyznaczyć dodatkowy termin stawiennictwa w urzędzie w celu dostarczenia wszystkich wymaganych na potrzeby rejestracji dokumentów i dokonania rejestracji. W przypadku niestawiennictwa osoby w powiatowym urzędzie pracy w terminie wskazanym przez PUP dane przekazane przez te osoby są usuwane z systemu teleinformatycznego publicznych służb zatrudnienia ${ }^{17}$.

14 Rozporządzenie Ministra Pracy i Polityki Społecznej z dnia 12 listopada 2012 r. w sprawie rejestracji bezrobotnych i poszukujących pracy, DzU 2012, poz. 1299.

${ }^{15} \mathrm{DzU} \mathrm{nr} 64$, poz. $565 \mathrm{z}$ późn. zm.

${ }^{16}$ M.in. aktualnego dowodu osobistego; dyplomu; świadectwa ukończenia szkoły oraz dokumentów potwierdzających uzyskanie kwalifikacji zawodowych, potwierdzających okresy zatrudnienia lub innej pracy zarobkowej; wszystkich świadectw pracy; zaświadczeń z ZUS-u, jeżeli takie były; decyzji o utracie prawa do renty czy świadczeń rehabilitacyjnych; orzeczenia o stopniu niepełnosprawności lub dokumentów o przeciwwskazaniach do wykonywania określonych prac; jeżeli ta osoba posiada gospodarstwo rolne, powinna dostarczyć zaświadczenie z urzędu gminy o powierzchni gospodarstwa rolnego oraz decyzję z KRUS o niepodleganiu ubezpieczeniu społecznemu rolników w celu uzyskania statusu osoby bezrobotnej.

$17 \$ 5$ pkt 7 Rozporządzenia Ministra Pracy i Polityki Społecznej z dnia 12 listopada 2012 r. w sprawie rejestracji bezrobotnych i poszukujących pracy, DzU 2012, poz.1299. 
„[...] W szczególnie uzasadnionych przypadkach starosta, mając na uwadze obiektywne okoliczności lub przeszkody, które uniemożliwiają przedłożenie kompletu dokumentów, może wyrazić zgodę na rejestrację osoby bezrobotnej nieposiadającej kompletu dokumentów lub która nie przekazała wymaganych danych"18.

Jeżeli jednak osoba przedłoży w urzędzie wszystkie wymagane dokumenty, zakładana jest jej karta rejestracyjna bezrobotnego w postaci elektronicznej. Może być ona w przyszłości modyfikowana, jeżeli osoba była wcześniej już na jej podstawie zarejestrowana w urzędzie pracy. Jeżeli nie nastąpiła zamiana w danych przekazanych w trakcie ostatniej rejestracji, bezrobotny składa tylko oświadczenie po wcześniejszej weryfikacji dokumentów, że przekazane uprzednio dane nie uległy zmianie. Dane zawarte w kartach rejestracyjnych tworzą rejestr bezrobotnych. Ważnym elementem $\mathrm{w}$ trakcie rejestracji jest zapewnienie poufności, by informacje składane przez osobę rejestrującą się nie były narażone na przedostanie się do wiadomości osób trzecich.

Po zarejestrowaniu powiatowy urząd pracy przekazuje osobie bezrobotnej kopię lub wydruk złożonego przez nią oświadczenia, wydruk z karty rejestracyjnej oraz informację o przysługujących jej prawach i obowiązkach wynikających z ustawy oraz formach pomocy określonych w ustawie.

Osoba bezrobotna, która zamierza zmienić miejsce zameldowania, powiadamia o tym fakcie właściwy urząd pracy, który wyłączy kartę bezrobotnego z rejestru bezrobotnych oraz prześle do właściwego urzędu dane zawarte w karcie rejestracyjnej $\mathrm{w}$ postaci elektronicznej oraz $\mathrm{w}$ wersji papierowej. W przypadku niestawiennictwa $\mathrm{w}$ powiatowym urzędzie pracy we wskazanym terminie ${ }^{19}$ właściwy urząd pracy informuje urząd, z którego otrzymał dokumenty, o braku stawiennictwa wskazanej osoby i wysyła zwrotnie do urzędu pierwotnego otrzymane dokumenty. Z powodu braku stawiennictwa $\mathrm{w}$ urzędzie pracy osoba ta wyłączona zostaje $\mathrm{z}$ rejestru bezrobotnych, co można również potraktować jako rezygnację z podjęcia pracy.

$\mathrm{Z}$ doświadczenia, które autorka wyniosła $\mathrm{w}$ toku przeprowadzania ankiet i wywiadów pogłębionych wśród osób bezrobotnych oraz pracowników powiatowych urzędów pracy, wynika, że niektóre urzędy pracy rejestrują osoby pozostające bez pracy w dniu zgłoszenia się, ale są również takie urzędy, które wyznaczają termin kilkudniowy oczekiwania na rejestrację. Oczekiwanie to spowodowane jest $\mathrm{z}$ jednej strony małą liczbą osób zatrudnionych w urzędach pracy, z drugiej zaś natężeniem prac, którymi obciążeni są pracownicy urzędów. To z kolej powoduje, że osoba chcąca dokonać formalności rejestracji pozostaje przez kilka dni bez ubezpieczenia, które zapewnia jej status osoby bezrobotnej. Wynika z tego wniosek, że powiatowe urzędy

$18 \$ 8$ pkt 5 , ibidem.

1914 dni od zmiany miejsca zameldowania. 
pracy powinny zwiększyć zatrudnienie, by zapewnić bieżącą obsługę osób, które chcą zarejestrować się jako osoby bezrobotne.

\section{Profilowanie pomocy dla bezrobotnych}

Pojęcie profilowania znane jest polityce społecznej od lat 90. XX w. Wykorzystywane jest np. przez Stany Zjednoczone, Australię, Kanadę, kraje europejskie, a w tym przez Danię, Holandię, Niemcy i Wielką Brytanię ${ }^{20}$. Jak wspomniano, wprowadzono je również w Polsce.

Profilowanie pomocy dla osób bezrobotnych jest nowym sposobem współpracy urzędu pracy z osobami bezrobotnymi, który w Polsce wprowadzony został Ustawą z dnia 14 marca 2014 r. o zmianie ustawy o promocji zatrudnienia i instytucjach rynku pracy oraz innych aktów prawnych ${ }^{21}$.

Profil pomocy charakteryzuje właściwy ze względu na sytuację i potrzeby osoby bezrobotnej zakres form pomocy określonych $\mathrm{w}$ ustawie. Celem profilowania jest zastosowanie wobec osoby bezrobotnej takiej pomocy, która najbardziej odpowiada jej aktualnej sytuacji i potrzebom. Cel ten można osiągnąć przez lepsze adresowanie instrumentów i usług, co pozwoli na racjonalne gospodarowanie środkami budżetowymi oraz dobrą efektywność działań ${ }^{22}$.

„Powiatowy urząd pracy, niezwłocznie po rejestracji, ustala dla bezrobotnego profil pomocy $[\ldots]^{\prime 23}$. Ustalenie profilu pomocy polega na przeprowadzeniu przez doradcę klienta wywiadu z osobą bezrobotną. Wywiad obejmuje 24 pytania, $8 \mathrm{z}$ nich generowanych jest przez urząd pracy w trakcie rejestracji, a na pozostałe 16 pytań odpowiada osoba bezrobotna. Doradca klienta zaznacza w elektronicznym kwestionariuszu odpowiedzi osoby bezrobotnej. Urzędnik, otrzymując wynik działania z programu Syriusz, wie, do którego profilu pomocy został przypisany bezrobotny oraz jaka forma pomocy mu w tym zakresie przysługuje. Oparte na wystandaryzowanej ocenie uzupełnionej rozmową $\mathrm{z}$ doradcą profilowanie pomocy dla osób bezrobotnych pozwala nie tylko na podejmowanie zobiektywizowanych decyzji,

\footnotetext{
${ }^{20}$ M. Wojdyło-Presner, Profilowanie bezrobotnych jako metoda przeciwdziałania dlugookresowemu bezrobociu, Wydawnictwo Naukowe UMK, Toruń 2009, s. 75-100.

${ }^{21}$ Rozporządzenie Ministra Pracy i Polityki Społecznej z dnia 14 maja 2014r. w sprawie profilowania pomocy dla bezrobotnego, DzU 2014, poz. 631.

22 J. Męcina, Niewykorzystane zasoby. Nowa polityka rynku prac, IPS UW, Oficyna Wydawnicza ASPRA-JR, Warszawa 2013, s.170.

${ }^{23}$ Art. 33 pkt 2b Ustawy z dnia 20 kwietnia 2004 r. o promocji zatrudnienia i instytucjach rynku pracy, DzU 201, poz. 567, 598.
} 
kto w jakim czasie będzie skierowany do aktywizacji przez urząd pracy lub agencję zatrudnienia, ale również na skuteczniejsze świadczenie pomocy w powrocie na rynek pracy $^{24}$ (rysunek 1).

\section{Rysunek 1. Rejestracja i profilowanie pomocy dla bezrobotnych}

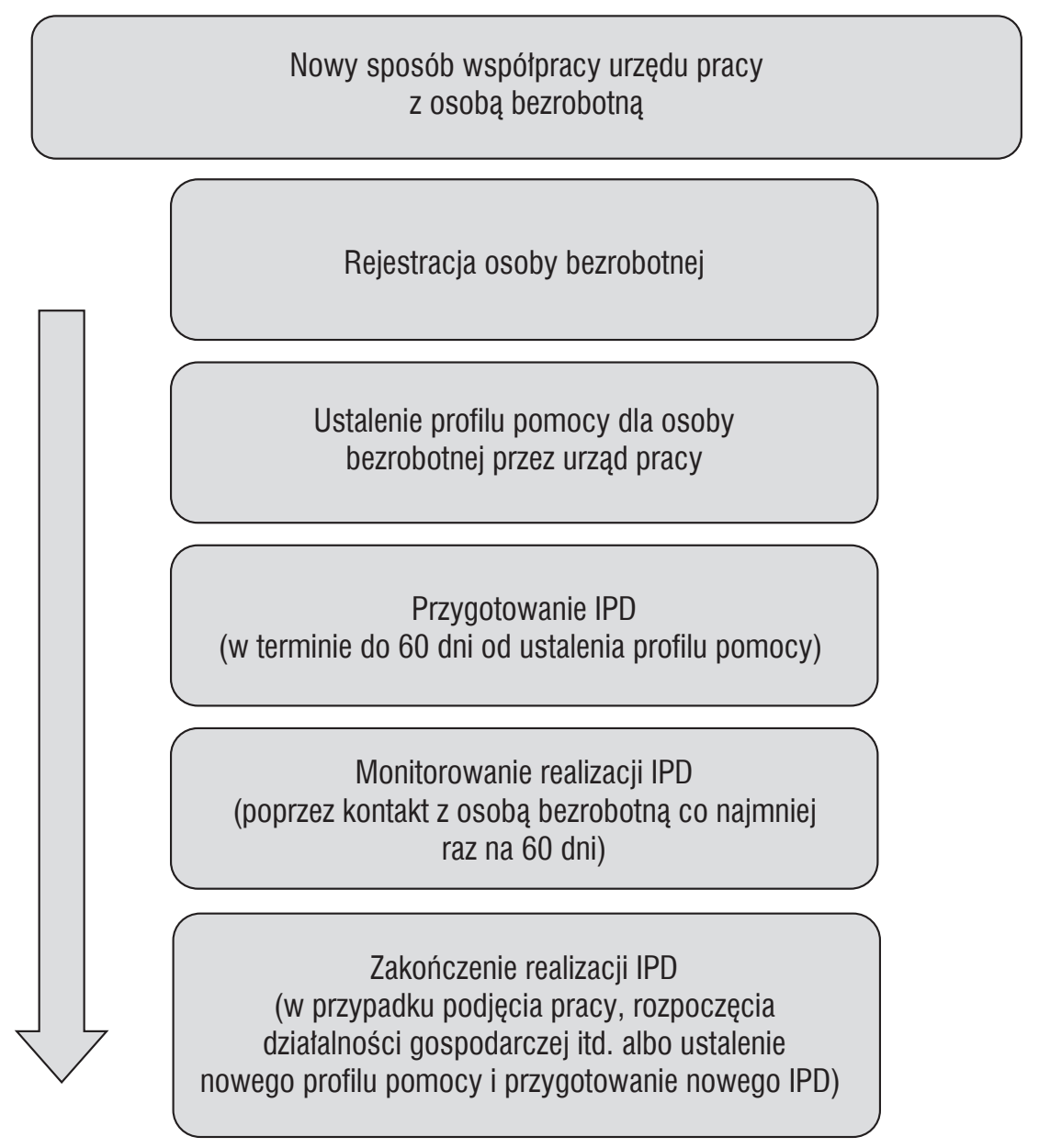

Źródło: Broszura informacyjna Ministerstwa Pracy i Polityki Społecznej.

Z doświadczenia nabytego przez autorkę w trakcie przeprowadzania badań wśród osób bezrobotnych wynika, że około 99,8\% ankietowanych nie pamięta, do którego profilu pomocy należy. Także wywiad pogłębiony ${ }^{25}$ wśród pracowników PUP potwierdził, że bezrobotni nie wiedzą lub nie pamiętają, do którego profilu pomocy należą, jednak wiedzą, jaka forma pomocy w danym profilu im przysługuje. Zdaniem

24 K. Ślebarska, Postawa wobec pracy jako predykator dążenia do zatrudnienia, w: Człowiek - praca - organizacja. Wymiary socjologiczne, psychologiczne i zarządcze, Wydawnictwo PCz, Częstochowa 2010, s.103-112.

25 Wywiad pogłębiony przeprowadzony wśród urzędników kilku PUP z województwa łódzkiego. Zgodnie z prośbą dyrekcji PUP nie wskazuję z nazwy powiatów, w których przeprowadzono badanie. 
pracowników powiatowych urzędów pracy bezrobotni doskonale orientują się, jakiej należy udzielić odpowiedzi na zadane przez doradcę klienta pytanie ${ }^{26}$, żeby znaleźć się w odpowiednim dla siebie profilu pomocy.

Znowelizowana ustawa o promocji zatrudnienia i instytucjach rynku pracy $\mathrm{w}$ art. 33 pkt $2 \mathrm{c}$ ustanawia trzy profile pomocy oraz formy pomocy dla osób bezrobotnych, zakwalifikowanych do danego profilu:

- I profil pomocy przewidziany jest dla osób aktywnie poszukujących pracy. Zakłada on, że urząd pracy może zastosować pośrednictwo pracy i pomóc w uzyskaniu oferty pracy.

Najmniej osób bezrobotnych znajduje się w pierwszym profilu pomocy. Potwierdza ten fakt również raport miesięczny ${ }^{27} \mathrm{z}$ października 2015 r., który określa, że do I profilu pomocy należy około 1,9\% sprofilowanych bezrobotnych.

- II profil pomocy przeznaczony jest dla osób, które wymagają wsparcia. Urząd pracy może zastosować dowolne formy pomocy określone w ustawie, takie jak szkolenia, skierowanie do prac interwencyjnych lub robót publicznych itd., z wyłączeniem Programu Aktywizacja i Integracja. W tym profilu pomocy według danych Ministerstwa Pracy i Polityki Społecznej znajduje się najwięcej osób bezrobotnych, tj. około $67,2 \%$ sprofilowanej populacji.

- III profil pomocy przeznaczony jest dla osób, które są oddalone od rynku pracy ${ }^{28}$. Urząd pracy może zastosować takie formy pomocy, jak: Program Aktywizacja i Integracja. Według danych MPiPS ten profil charakteryzuje około 30,9\% populacji bezrobotnych. Zdaniem autorki znajdują się w nim osoby, które nie chcą w ogóle pracować (np. długotrwale bezrobotni, korzystający z pomocy MOPS lub zarejestrowani bezrobotni, którzy mając ubezpieczenie zdrowotne, chętnie pracują na czarno), ale także bezrobotne kobiety, które ze względu na opiekę nad chorym członkiem rodziny lub małym dzieckiem w obecnej sytuacji nie mogą podjąć pracy. W tym gronie znajdują się także osoby, które ze względu na stan zdrowia nie mogą podjąć pracy.

Po zakończeniu wywiadu $\mathrm{z}$ bezrobotnym doradca klienta informuje bezrobotnego, do którego profilu pomocy został zaklasyfikowany oraz umawia się z bezrobotnym na ustalenie Indywidualnego Planu Działania ${ }^{29}$. IPD musi być przygoto-

\footnotetext{
${ }^{26}$ Pytania dla bezrobotnych generowane są przez program Syriusz, za pomocą którego ustala się profil pomocy dla osoby bezrobotnej.

27 MPiPS, Departament Rynku Pracy, Raport miesięczny - październik 2015 r., Bezrobocie rejestrowane w Polsce, s. 3.

${ }_{28}$ Przez oddalenie od rynku pracy należy rozumieć te czynniki, które stoją na przeszkodzie w wejściu lub powrocie na rynek pracy.

${ }^{29}$ Indywidualny Plan Działania (IPD), ustalany przez doradcę klienta w PUP dla każdej sprofilowanej osoby bezrobotnej.
} 
wany nie później niż 60 dni od dnia ustalenia profilu pomocy. Pomoc w ramach danego profilu pomocy jest udzielana przez urząd pracy w okresie nie dłuższym niż: 180 dni dla I profilu pomocy, 540 dni dla II profilu pomocy, 720 dni dla III profilu pomocy. W trakcie realizacji IPD urząd pracy co najmniej raz na 60 dni kontaktuje się z osobą bezrobotną w celu monitorowania sytuacji i postępów we wprowadzaniu w życie działań przewidzianych dla bezrobotnego. Realizacja Indywidualnego Planu Działania kończy się w przypadku podjęcia pracy przez bezrobotnego, rozpoczęcia działalności gospodarczej albo ustalenia nowego profilu pomocy i przygotowania nowego IPD. W tabeli 1 przedstawiono zestawienie podziału bezrobotnych w 2015 r. według liczby osób z ustalonym profilem pomocy oraz stopy bezrobocia.

Tabela 1. Bezrobotni według ustalonego profilu pomocy i stopy bezrobocia w Polsce

\begin{tabular}{|c|c|c|c|c|c|c|}
\hline \multirow{2}{*}{$\begin{array}{c}\text { Na koniec } \\
\text { miesiąca 2015 r. }\end{array}$} & \multirow{2}{*}{$\begin{array}{c}\text { Liczba bezrobotnych } \\
\text { (w tys.) }\end{array}$} & \multirow{2}{*}{$\begin{array}{c}\text { Liczba bezrobotnych } \\
\text { z ustalonym profilem (w tys.) }\end{array}$} & $\begin{array}{c}\text { Stopa bezrobocia } \\
\text { (w \%) }\end{array}$ & \multicolumn{3}{|c|}{ Profile (w \%) } \\
\cline { 5 - 7 } & 1918,6 & 1822,7 & 12,0 & 4,2 & 67,9 & 27,9 \\
\hline I & 1918,7 & 1840,3 & 12,0 & 4,2 & 67,9 & 27,9 \\
\hline II & 1860,6 & 1782,3 & 11,7 & 2,9 & 69,0 & 28,0 \\
\hline III & 1782,2 & 1708,1 & 11,2 & 2,6 & 68,8 & 28,7 \\
\hline IV & 1702,1 & 1633,7 & 10,8 & 2,3 & 68,4 & 29,4 \\
\hline V & 1622,0 & 1556,9 & 10,3 & 2,0 & 67,7 & 30,3 \\
\hline VI & 1585,7 & 1518,5 & 10,1 & 1,9 & 67,4 & 30,7 \\
\hline VII & 1563,5 & 1495,9 & 10,0 & 1,8 & 67,4 & 30,8 \\
\hline VIII & 1539,4 & 1467,4 & 9,7 & 1,6 & 67,2 & 31,2 \\
\hline IX & 1516,9 & 1451,9 & 9,6 & 1,9 & 67,2 & 30,9 \\
\hline X & & & & & \\
\hline
\end{tabular}

Źródło: Raport miesięczny za miesiące I-X 2015 r. dotyczący bezrobocia rejestrowanego w Polsce, opublikowany przez MPiPS.

Najmniej osób znajduje się w I profilu pomocy. Ich liczba uzależniona jest m.in. od pory roku. I tak zgodnie z raportem MPiPS w styczniu i lutym 2015 r. było ich zaledwie 4,2\%. Od marca tegoż roku udział w tej grupie systematycznie maleje, osiągając poziom 1,6\% we wrześniu $2015 \mathrm{r}$. W tym profilu pomocy znajdują się osoby, które bez wsparcia powiatowego urzędu pracy poradzą sobie w znalezieniu pracy. Jest ich stosunkowo niewiele $\mathrm{w}$ porównaniu $\mathrm{z}$ dwoma pozostałymi profilami.

Najliczniejszą grupę charakteryzuje II profil pomocy. Bez względu na porę roku, znajduje się w nim około $67 \%$ sprofilowanych osób. Jest to najbardziej pożądany profil pomocy przez bezrobotnych. Znajdujący się w nim bezrobotny może uzyskać od urzędu pracy konkretną pomoc w postaci przeszkolenia w celu zmiany kwalifikacji lub otrzymania określonej kwoty pieniędzy na założenie własnej firmy. Z kolei 
przedsiębiorcy mogą uzyskać z PUP dofinansowanie w celu utworzenia nowego miejsca pracy dla osoby jej poszukującej.

Liczny jest również III profil pomocy. Liczba osób przyporządkowanych do tego profilu od stycznia 2015 r. wzrosła z 27,9\% do 31,2\% we wrześniu 2015 r. Są to osoby najbardziej oddalone od rynku pracy, którym najtrudniej powrócić na ten rynek. Jest to spowodowane m.in. brakiem umiejętności, wykształcenia, chorobą bądź koniecznością stałego opiekowania się chorą lub starszą osobą z rodziny.

Z punktu widzenia systemu profilowania pomocy dla bezrobotnych wygląda on względnie dobrze. Struktura osób zarejestrowanych w powiatowych urzędach pracy według trzech profili pomocy pokazuje jednak, że jest między nimi wyraźna dysproporcja $^{30}$. Można przypuszczać, że profilowanie albo jest za „ostre”, albo bezrobotni nie są gotowi do podjęcia pracy.

\section{Dane statystyczne i ich wykorzystanie}

Z badań statystyki publicznej, instytucji naukowych oraz wielu innych korzystają nie tylko organy państwa, przedsiębiorcy, studenci i uczniowie, ale także ogół społeczeństwa. To, co dzieje się w społeczeństwie, pokazują nam nie tylko spisy powszechne, ale również systematycznie prowadzone badania w zakresie gospodarstw domowych, bezrobotnych czy przedsiębiorców. Tak zgromadzone dane służą do różnych analiz. Na ich podstawie opracowywane są publikacje dotyczące rozmaitych dziedzin życia. Dzięki nim można ustalić zmienność zjawisk masowych, tendencji ich przekształceń w czasie. Dane te stanowią również podstawę do podejmowania strategicznych decyzji ekonomicznych, społecznych i administracyjnych na niemal wszystkich szczeblach zarządzania (od struktur lokalnych po centralne). Wyniki analiz prezentowane są w ogólnie dostępnych publikacjach Głównego Urzędu Statystycznego, Urzędu Statystycznego Unii Europejskiej (Eurostat) oraz wielu innych instytucji w wersji papierowej lub elektronicznej, w formie raportów czy też szczegółowych opracowań. Celem analizy statystycznej jest uzyskanie jak największej wiedzy z zebranych danych.

Zjawisko bezrobocia, będące jednym z głównych problemów społecznych, gospodarczych oraz politycznych, jest wyzwaniem dla każdego kraju, który chce zminimalizować je choćby do stopy bezrobocia naturalnego, liczącego około 5\%. Jednym

30 Według danych Ministerstwa Pracy i Polityki Społecznej z września 2015 r. w I profilu było około 1,6\%, w II profilu $67,2 \%$, natomiast w III profilu $31,2 \%$ sprofilowanych bezrobotnych. 
Z warunków ustalenia tego jest dobra statystyka, dzięki której oceniamy stopę bezrobocia, strukturę bezrobocia (według cech demograficznych i społecznych) oraz jego rozmieszczenie przestrzenne.

Wiele instytucji, w tym przede wszystkim Główny Urząd Statystyczny, Ministerstwo Pracy i Polityki Społecznej, uczelnie, instytuty PAN, a także Narodowy Bank Polski, prowadzi badania i zbiera informacje dotyczące bezrobocia w Polsce. Dane te służą do uzyskania informacji, jakie jest w danym okresie bezrobocie, jak kształtuje się stopa bezrobocia w danym roku, w jakich zawodach jest deficyt, a w jakich nadwyżka. Statystyka ta odzwierciedla sytuację osób bezrobotnych na polskim rynku pracy, a zarazem służy instytucjom państwowym do zmiany prawa, strategii oraz pomocy tej grupie społecznej, która pozostała bez pracy.

Dane statystyczne dotyczące bezrobocia sytuują również Polskę na tle państw Unii Europejskiej, informując, w jakim stanie znajduje się polska gospodarka oraz jakie są zasoby niewykorzystanego kapitału ludzkiego.

\section{Bezrobotni w świetle badań Narodowego Banku Polskiego}

Narodowy Bank Polski zajmuje się badaniem, analizą i prognozą różnych wskaźników gospodarczych. Prowadzi badania między innymi w zakresie prognozy inflacji, koniunktury gospodarczej, badania rynku pracy i rynku nieruchomości. Bank Centralny, „realizując ustawowy cel, jakim jest utrzymanie stabilnego poziomu cen"31, prowadzi od 2006r. badania zjawisk zachodzących na rynku pracy (wśród osób bezrobotnych i przedsiębiorców), mających wpływ na kształtowanie się cen. Badanie pilotażowe rynku pracy na terenie województwa świętokrzyskiego przeprowadził na przełomie lutego i marca 2006 r. Oddział Okręgowy Narodowego Banku Polskiego w Kielcach. Założenia badawcze przygotował zespół w składzie: prof. dr hab. Leszek Zienkowski, dr Wiesław Gumuła, dr Adam Czyżewski oraz mgr Wiktor Wojciechowski. Dzięki badaniu została opracowana diagnoza ww. rynku pracy oraz narzędzia badawcze, które wykorzystano w badaniach ogólnopolskich w latach 2006-2015. Od października 2006 r. do października 2010 r. badania wśród osób bezrobotnych odbywały się dwa razy w roku. Kwestionariusze ankiet opracowywane były we współpracy z Departamentem Analiz Makroekonomicznych i Strukturalnych Narodowego Banku Polskiego. Od wiosny 2011 r. badania rynku

${ }^{31}$ Art. 3.1 Ustawy z dnia 29 sierpnia 1997 r. o Narodowym Banku Polskim, DzU 2013, poz. 908 z późn. zm. 
pracy wśród osób bezrobotnych przeprowadzane są raz w roku. Piecze nad nimi sprawuje Instytut Ekonomiczny Narodowego Banku Polskiego. Pytania istotne z perspektywy prowadzenia polityki monetarnej, zawarte $\mathrm{w}$ ankiecie badawczej, zaakceptowane zostały przez Instytut Ekonomiczny NBP. Poza cechami społeczno-demograficznymi dotyczą one poszukiwania pracy, dojazdów do pracy, mobilności bezrobotnych, oczekiwań płacowych, niedopasowania strukturalnego oraz procesów cenotwórczych - w tym wyznaczania płac ${ }^{32}$. W 2014 r. wprowadzono w Polsce profilowanie pomocy dla osób bezrobotnych, natomiast od $2015 \mathrm{r}$. w kwestionariuszu ankiety dla bezrobotnych Narodowego Banku Polskiego zawarte zostały pytania dotyczące tej procedury. Świadczy to o zainteresowaniu banku centralnego zmianami zachodzącymi na rynku pracy.

Badanie rynku pracy wśród osób bezrobotnych prowadzone jest cyklicznie przy udziale ankieterów, którymi są pracownicy oddziałów okręgowych Narodowego Banku Polskiego. To z kolei powoduje, że ankieter poznaje codzienne problemy osób poszukujących pracy oraz możliwe sposoby ich zapobiegania i radzenia sobie w takiej sytuacji. Zapraszając respondenta do wzięcia udziału w ankiecie, ankieter spotyka się z różną reakcją ze strony bezrobotnych. Są osoby, które czekając na rozmowę $\mathrm{z}$ urzędnikiem urzędu pracy, chętnie decydują się na wzięcie udziału w badaniu, ale są również tacy, którym się śpieszy i nie mają czasu bądź też krytykują obecną sytuację na rynku pracy w Polsce.

Wyniki przeprowadzonych trzynastu edycji badań rynku pracy wśród osób bezrobotnych dostępne są na stronie internetowej Narodowego Banku Polskiego ${ }^{33}$ w zakładce publikacje - rynek pracy. W sumie przez dziewięć lat badań rynku pracy wśród osób bezrobotnych Narodowy Bank Polski przeprowadził ponad 42 tys. wywiadów ${ }^{34}$. Było to możliwe dzięki udziałowi pracowników, ze wszystkich szesnastu Oddziałów Okręgowych Narodowego Banku Polskiego, którzy doskonale sprawdzili się w roli ankieterów. Jest to niezwykle trudna praca, wymagająca czasami również opanowania się, ponieważ zdarzają się respondenci niechętnie odpowiadający na pytania, a dodatkowo obwiniający innych za swój los.

W tabeli 2 przedstawiono liczbę bezrobotnych respondentów według płci objętych kolejnymi edycjami badań, które były prowadzone przez Narodowy Bank Polski.

32 Raport Narodowego Banku Polskiego z 2013 r., Badanie ankietowe rynku pracy, Narodowy Bank Polski, Warszawa 2013, s. 3.

33 www.nbp.pl

${ }^{34}$ Brak danych z I oraz XIV edycji badań rynku pracy (według autorki artykułu w 2006 r. przeprowadzono około 2400 wywiadów, a w 2015 r. około 4750 ankiet). 
Tabela 2. Próby badawcze bezrobotnych badanych przez NBP w latach 2006-2015

\begin{tabular}{|l|c|c|c|}
\hline \multicolumn{1}{|c|}{ Rok i miesiąc badania } & Kobiety & Mężczyźni & Ogółem \\
\hline X 2006r. & b.d. & b.d. & 2400 \\
\hline V 2007r. & 1437 & 963 & 2400 \\
\hline X 2007r. & 1224 & 766 & 1990 \\
\hline V 2008r. & 1240 & 760 & 2000 \\
\hline X 2008 r. & 1209 & 791 & 2000 \\
\hline V 2009r. & 1163 & 837 & 2000 \\
\hline X 2009r. & 1145 & 855 & 2000 \\
\hline V 2010r. & 1114 & 886 & 2000 \\
\hline X 2010r. & 1174 & 826 & 2000 \\
\hline V 2011r. & 2052 & 1948 & 4000 \\
\hline V 2012r. & 2445 & 2307 & 4752 \\
\hline V 2013r. & 2508 & 2244 & 4752 \\
\hline V 2014r. & 2626 & 2366 & 4992 \\
\hline V 2015r. & b.d. & b.d. & b.d. \\
\hline Ogółem & 19337 & 15549 & 34886 \\
\hline
\end{tabular}

Uwaga: Zgodnie z konceptualizacją ogólnopolskich badań rynku pracy, prowadzonych przez dr. Wiesława Gumuła (Narodowy Bank Polski Oddział Okręgowy w Kielcach), badaniem zostały objęte wszystkie kategorie bezrobotnych, które zostały wyodrębnione według kryterium czasu przebywania na bezrobociu w próbie liczącej 150 respondentów w każdym województwie w Polsce. Trudno jest określić w pierwszej edycji badania rynku pracy wśród osób bezrobotnych podział ze względu na płeć, ponieważ baza, którą otrzymała autorka, jest niekompletna.

Żródło: Baza danych rynku pracy NBP z lat 2006-2015.

Badanie rynku pracy wśród osób bezrobotnych rozpoczęte jesienią 2006 r. obejmowało przez dwie edycje badań próbę badawczą 2400 respondentów. W związku z tym, że baza danych z 2006 r. otrzymana od Instytutu Ekonomicznego Narodowego Banku Polskiego ${ }^{35}$ jest niekompletna, nie zostały wskazane liczby bezrobotnych według płci. Od jesieni 2007 r. do maja 2010 r. próby badawcze bezrobotnych pozostawały na niezmienionym poziomie w liczbie 2000 respondentów. Przejęcie badania rynku pracy przez Instytut Ekonomiczny spowodowało w kolejnych latach zwiększenie prób badawczych z 2000 respondentów w październiku 2010 r. do 4992 respondentów w maju $2014 \mathrm{r}$. We wszystkich edycjach badania rynku pracy prowadzonych przez Narodowy Bank Polski większą liczbę ankiet wśród bezrobotnych respondentów pozyskuje się od kobiet niż od mężczyzn. Jest to odwzorowaniem statystyki powiatowych urzędów pracy, Głównego Urzędu Statystycznego, która potwierdza fakt, że kobietom trudniej jest znaleźć pracę.

${ }^{35}$ Dysponentem baz danych wszystkich edycji rynku pracy jest Instytut Ekonomiczny NBP. 
W tabeli 3 wskazano bezrobotnych respondentów według wykształcenia. Wynika z niej, że od maja 2007 r. do maja 2014 r. badaniami objęci byli respondenci posiadający wykształcenie zasadnicze i niższe, średnie oraz wyższe. W badanym okresie udział wykształcenia zasadniczego i niższego wśród badanych bezrobotnych w powiatowych urzędach pracy zmniejszył się o 11,1 pkt. proc. Udział osób z wykształceniem średnim zwiększył się o 6,6 pkt. proc., a udział osób z wykształceniem wyższym zwiększył się o 4,5 pkt. proc. Oznacza to, że bezrobotni w Polsce mają coraz lepsze kwalifikacje, potwierdzone świadectwami szkolnymi. Z tego wynikałoby, że pracodawcy nie powinni mieć kłopotów z pozyskiwaniem pracowników o wymaganych kwalifikacjach, a jednak te kłopoty są i zatrudniający odpowiednich osób poszukują.

Tabela 3. Bezrobotni objęci badaniem NBP według wykształcenia w latach 2006-2015

\begin{tabular}{|l|c|c|c|c|c|}
\hline \multirow{2}{*}{ Rok i miesiąc } & \multicolumn{2}{|c|}{ Ogółem } & \multicolumn{3}{c|}{ Wykształcenie (w \%) } \\
\cline { 2 - 6 } & liczba (w tys.) & udział (w \%) & zasadnicze i niższe & średnie & wyższe \\
\hline X 2006r. & 2400 & b.d. & b.d. & b.d. & b.d. \\
\hline V 2007 r. & 2400 & 6,9 & 56,8 & 34,1 & 9,1 \\
\hline X 2007 r. & 2000 & 5,7 & 60,8 & 30,1 & 9,1 \\
\hline V 2008 r. & 2000 & 5,7 & 60,6 & 9,0 & 30,4 \\
\hline X 2008 r. & 2000 & 5,7 & 58,1 & 33,7 & 8,2 \\
\hline V 2009 r. & 2000 & 5,7 & 58,0 & 33,2 & 8,8 \\
\hline X 2009 r. & 2000 & 5,7 & 57,5 & 34,5 & 8,0 \\
\hline V 2010r. & 2000 & 5,7 & 55,7 & 34,7 & 9,6 \\
\hline X 2010r. & 2000 & 5,7 & 55,7 & 34,5 & 9,8 \\
\hline V 2011 r. & 4000 & 11,5 & 47,0 & 42,0 & 11,0 \\
\hline V 2012 r. & 4752 & 13,6 & 47,9 & 38,8 & 13,3 \\
\hline V 2013r. & 4753 & 13,6 & 47,1 & 39,1 & 13,8 \\
\hline V 2014 r. & 4991 & 14,3 & 45,7 & 40,7 & 13,6 \\
\hline V 2015 r. & b.d & b.d. & b.d. & b.d. & b.d. \\
\hline Suma & 34896 & 100,0 & 52,1 & 35,6 & 12,3 \\
\hline
\end{tabular}

Źródło: Baza danych rynku pracy NBP z lat 2006-2015.

Oznacza to, że system szkolny w Polsce nie zapewnia rynkowi pracy wykształconych absolwentów z odpowiednimi kwalifikacjami, których pracodawcy poszukują. 


\section{Profilowanie pomocy dla osób bezrobotnych w świetle opinii pracowników PUP}

Pierwszą osobą, która po przeprowadzeniu rozmowy z bezrobotnym widzi ustalony jej profil pomocy, jest urzędnik powiatowego urzędu pracy. Stąd też interesujące jest pytanie, jak pracownicy urzędów widzą proces profilowania pomocy oraz jego skuteczność. W tym celu autorka przeprowadziła badanie w kilku powiatowych urzędach pracy ${ }^{36} \mathrm{w}$ województwie łódzkim, wśród 39 respondentów urzędników, którzy zajmują się na co dzień profilowaniem pomocy dla bezrobotnych.

Z tych badań wynika, że 17 ankietowanych osób oceniło profilowanie pomocy dla bezrobotnych jako dyskryminujące, ponieważ w różnych profilach przysługuje inna forma pomocy dla osób zarejestrowanych. Z drugiej jednak strony, aż 21 pracowników ocenia je pod kątem efektywności jako dobre. Na zadane pytanie, czy profilowanie pomocy ułatwia urzędnikowi pracę w kontakcie $\mathrm{z}$ bezrobotnym, 24 biorących udział w wywiadzie uznało, że tak. 19 odpowiedzi twierdzących uzyskano na pytanie dotyczące zadowolenia bezrobotnych z profilowania pomocy. Ankietowani ci uważali, że bezrobotni są zadowoleni z profilowania pomocy, druga połowa urzędników twierdziła jednak, że bezrobotni woleliby poprzednie rozwiązanie, czyli zwykłą rejestrację. 12 spośród badanych 39 respondentów PUP opowiedziało się za likwidacją profilowania pomocy. Zdaniem tych pracowników urzędów pracy każdy profil pomocy wymaga tej samej pracy $\mathrm{z}$ bezrobotnym, ale $\mathrm{w}$ ramach profilów pomocy terminy i formy pomocy przewidziane dla bezrobotnego są różne. Inną sprawą jest brak posiadanych środków finansowych na pomoc dla bezrobotnych. Wszyscy objęci badaniem urzędnicy PUP, zajmujący się na co dzień profilowaniem pomocy dla bezrobotnych, stwierdzili zgodnie, że informują bezrobotnego, do którego profilu pomocy należy. Ich zdaniem nie ma to znaczenia, ponieważ bezrobotni są zorientowani, $w$ jakim profilu dana forma pomocy im przysługuje. 31 opiniodawców uznało, że profilowanie pomocy nie przyspiesza wejścia pracownika do grona osób pracujących. Zgadzają się z tym również osoby poszukujące pracy, twierdząc, że w powiatowym urzędzie pracy nie znajdzie się potencjalnego pracodawcy. Bezrobotni pytani w kwestionariuszu Narodowego Banku Polskiego w jaki sposób poszukują pracy, twierdzą, że wysyłają e-mail zawierający CV, pytają o pracę znajomych, szukają jej w prasie oraz w internecie. Te metody w opinii badanych okazują się

36 Zgodnie z prośbą trzech PUP z województwa łódzkiego dane statystyczne (próba - 39 wywiadów) uzyskane w ramach wywiadu pogłębionego będą podawane agrarnie, bez wskazania miasta, powiatu, w którym zostały przeprowadzone. 
skuteczniejsze. Jak z powyższego wynika, profilowanie pomocy dla bezrobotnych nie jest jednoznacznie oceniane wśród urzędników i bezrobotnych.

\section{Mocne i słabe strony profilowania pomocy dla bezrobotnych}

Profile pomocy dla bezrobotnych to nic innego jak klasyfikowanie ich do jednej z trzech grup, które charakteryzują się aktywnością, wsparciem bądź oddaleniem od rynku pracy. W tabeli 4 przedstawione zostały pozytywne i negatywne strony profilowania pomocy dla bezrobotnych, które stosowane jest na polskim rynku pracy od ponad roku.

Tabela 4. Zalety i wady profilowania bezrobotnych

\begin{tabular}{|c|c|c|c|}
\hline Lp. & Temat & Zalety & Wady \\
\hline \multirow[t]{3}{*}{1} & \multirow[t]{3}{*}{$\begin{array}{l}\text { Rejestracja } \\
\text { bezrobotnych }\end{array}$} & $\begin{array}{l}\text { - poddanie się rejestracji jest działaniem } \\
\text { niezbędnym do uzyskania statusu } \\
\text { bezrobotnego }\end{array}$ & $\begin{array}{l}\text { - rejestracja bezrobotnego w urzędzie pracy } \\
\text { wyłącza możliwość rejestracji w tym } \\
\text { samym urzędzie pracy jako poszukującego } \\
\text { pracy oraz posiadania takiego statusu } \\
\text { przez okres posiadania statusu } \\
\text { bezrobotnego }\end{array}$ \\
\hline & & $\begin{array}{l}\text { - akt rejestracji stanowi formalną przesłankę } \\
\text { uzyskania statusu bezrobotnego, dostarcza } \\
\text { wstępnej wiedzy o właściwościach } \\
\text { i oczekiwaniach osób rejestrujących się; } \\
\text { jest źródłem informacji statystycznych; } \\
\text { daje możliwość korzystania z pomocy } \\
\text { świadczonej przez urzędy pracy } \\
\text { - z mocy prawa rejestrujący się nabywa } \\
\text { ubezpieczenie zdrowotne }\end{array}$ & $\begin{array}{l}\text { - w niektórych urzędach na zarejestrowanie } \\
\text { się trzeba czekać 7-10 dni }\end{array}$ \\
\hline & & $\begin{array}{l}\text { - rejestracja bezrobotnego następuje } \\
\text { po przedstawieniu przez tę osobę } \\
\text { dokumentów niezbędnych do ustalenia } \\
\text { jego statusu i uprawnień }\end{array}$ & $\begin{array}{l}\text { - osoba rejestrująca się musi przygotować } \\
\text { wiele dokumentów, które są niezbędne } \\
\text { do otrzymania statusu osoby bezrobotnej } \\
\text { (m.in. dowód osobisty albo inny dokument } \\
\text { tożsamości; dyplom, świadectwo } \\
\text { ukończenia szkoły lub świadectwo szkolne } \\
\text { bądź zaświadczenie o ukończeniu kursu } \\
\text { lub szkolenia; świadectwa pracy oraz } \\
\text { inne dokumenty niezbędne do ustalenia } \\
\text { jej uprawnień; dokument stwierdzający } \\
\text { przeciwwskazania do wykonywania } \\
\text { określonych prac, jeżeli taki dokument } \\
\text { posiada) }\end{array}$ \\
\hline
\end{tabular}




\begin{tabular}{|c|c|c|c|}
\hline \multirow[t]{4}{*}{ Lp. } & Temat & Zalety & Wady \\
\hline & & $\begin{array}{l}\text { - pracownik urzędu pracy podczas } \\
\text { rejestracji bezrobotnego ma obowiązek } \\
\text { dokumentować wszystko, co od } \\
\text { niego usłyszy; jest też obowiazzany } \\
\text { wyjaśnić ewentualne rozbieżności, } \\
\text { aby w ten sposób uniknać przyznania } \\
\text { statusu bezrobotnego osobie do tego } \\
\text { nieuprawnionej }\end{array}$ & $\begin{array}{l}\text { - ze strony pracownika PUP czynności } \\
\text { podczas rejestracji wymagają poświęcenia } \\
\text { więcej czasu bezrobotnemu oraz } \\
\text { wypełnienia dokumentacji }\end{array}$ \\
\hline & & $\begin{array}{l}\text { - osoba zarejestrowana jako bezrobotna } \\
\text { zawiadamia PUP: osobiście albo za } \\
\text { pośrednictwem formularza elektronicznego } \\
\text { o wszelkich zmianach w danych } \\
\text { przekazanych w trakcie rejestracji oraz } \\
\text { w złożonych oświadczeniach, w terminie } \\
7 \text { dni od dnia ich wystąpienia }\end{array}$ & \\
\hline & & $\begin{array}{l}\text { - niezwłocznie po rejestracji w PUP ustalany } \\
\text { jest dla bezrobotnego profil pomocy } \\
\text { oraz zakres form pomocy określonych } \\
\text { w ustawie }\end{array}$ & \\
\hline \multirow[t]{7}{*}{2} & \multirow[t]{7}{*}{$\begin{array}{l}\text { Profilowanie } \\
\text { pomocy dla osób } \\
\text { bezrobotnych }\end{array}$} & $\begin{array}{l}\text { - związane jest z rozmową, osobistym } \\
\text { spotkaniem z bezrobotnym, niezbędna jest } \\
\text { wizyta bezrobotnego w urzędzie pracy }\end{array}$ & \\
\hline & & $\begin{array}{l}\text { - przypisanie do danego profilu pomocy } \\
\text { określa zakres możliwości, z jakich } \\
\text { bezrobotny może skorzystać }\end{array}$ & $\begin{array}{l}\text { - sztywne określenie katalogów form } \\
\text { pomocy } \\
\text { - brak funduszy w PUP na różne formy } \\
\text { pomocy dla bezrobotnych w ramach } \\
\text { danego profilu }\end{array}$ \\
\hline & & $\begin{array}{l}\text { - szybko można określić osobe, która } \\
\text { rzeczywiście poszukuje pracy (to osoby } \\
\text { znajdujące się w I i ll profilu) }\end{array}$ & $\begin{array}{l}\text { - trzy profile pomocy nie do końca } \\
\text { odwzorowują rynek pracy oraz typy } \\
\text { bezrobotnych, np. w Ill profilu znajdują } \\
\text { się osoby, które nigdy nie pracowały wraz } \\
\text { z osobami, które są obecnie chore lub } \\
\text { sprawują opiekę nad osobą chorą albo } \\
\text { są w ciąży, na urlopie macierzyńskim lub } \\
\text { wychowawczym }\end{array}$ \\
\hline & & $\begin{array}{l}\text { - przy ustaleniu profilu pomocy dla } \\
\text { bezrobotnego PUP będzie dokonywać } \\
\text { analizy sytuacji bezrobotnego i jego } \\
\text { szans na rynku pracy, biorąc pod uwage } \\
\text { oddalenie bezrobotnego od rynku pracy } \\
\text { i jego gotowość do wejścia lub powrotu } \\
\text { na rynek pracy }\end{array}$ & $\begin{array}{l}\text { - urzędnik PUP jest osobą rejestrującą } \\
\text { odpowiedzi osoby bezrobotnej } \\
\text { w programie informatycznym Syriusz; } \\
\text { to program, a nie urzędnik kwalifikuje } \\
\text { daną osobę do wskazanego zgodnie } \\
\text { z odpowiedziami bezrobotnego profilu } \\
\text { pomocy }\end{array}$ \\
\hline & & $\begin{array}{l}\text { - możliwość kontaktowania się } \\
\text { z urzędnikiem PUP telefonicznie, poprzez } \\
\text { pocztę elektroniczną lub osobiście }\end{array}$ & $\begin{array}{l}\text { - możliwość kontaktowania się telefonicznie } \\
\text { osoby bezrobotnej z urzędnikiem urzędu } \\
\text { pracy w sprawie aktywnego poszukiwania } \\
\text { pracy }\end{array}$ \\
\hline & & $\begin{array}{l}\text { - taki sam okres (60 dni) na przygotowanie } \\
\text { IPD przez urzędnika PUP dla każdego } \\
\text { bezrobotnego }\end{array}$ & $\begin{array}{l}\text { - podczas profilowania urzędnik ma } \\
\text { więcej pracy z danym bezrobotnym, nie } \\
\text { przekłada się to jednak na szybsze wejście } \\
\text { poszukującego pracy na ten rynek }\end{array}$ \\
\hline & & $\begin{array}{l}\text { - urzędnik ma możliwość lepszego poznania } \\
\text { bezrobotnego, jego sytuacji }\end{array}$ & $\begin{array}{l}\text { - bezrobotni dobrze wiedza, jak odpowiadać } \\
\text { na pytania urzędnika, żeby znaleźć się } \\
\text { w odpowiednim dla siebie profilu }\end{array}$ \\
\hline
\end{tabular}




\begin{tabular}{|c|c|c|c|}
\hline Lp. & \multirow[t]{2}{*}{ Temat } & \multirow{2}{*}{$\begin{array}{l}\text { Zalety } \\
\text { - podział na profile pomocy ewidentnie } \\
\text { wskazuje, ile osób w rzeczywistości } \\
\text { poszukuje pracy }\end{array}$} & \multirow{2}{*}{$\begin{array}{l}\text { Wady } \\
\text { - jest wielu bezrobotnych, którzy pracują } \\
\text { na czarno }\end{array}$} \\
\hline & & & \\
\hline & & & $\begin{array}{l}\text { - bezrobotny w każdym momencie, } \\
\text { na własne życzenie może wyrejestrować } \\
\text { się z rejestru osób bezrobotnych }\end{array}$ \\
\hline & & $\begin{array}{l}\text { - istnieje możliwość skorygowania profilu } \\
\text { pomocy bezrobotnego w przypadku } \\
\text { zmiany jego sytuacji np. zdrowotnej } \\
\text { lub opiekuńczej; bezrobotni obchodzą } \\
\text { system, wyrejestrowują się i ponownie } \\
\text { rejestruja, by przejść od początku proces } \\
\text { profilowania pomocy, odpowiadając } \\
\text { na pytania w taki sposób, żeby znaleźć } \\
\text { się w najlepszym, Il profilu, który daje } \\
\text { największe szanse na znalezienie pracy }\end{array}$ & $\begin{array}{l}\text { - potencjalnie, każdy niezadowolony } \\
\text { bezrobotny, który uzna, że jest } \\
\text { w nieodpowiednim dla siebie profilu } \\
\text { pomocy, może wyrejestrować sie, by } \\
\text { ponownie przejść proces rejestracji } \\
\text { i profilowania }\end{array}$ \\
\hline & & $\begin{array}{l}\text { - ponowne ustalenie profilu pomocy } \\
\text { nasteppuje obligatoryjnie, jeżeli w wyniku } \\
\text { realizacji IPD nie udało się doprowadzić } \\
\text { bezrobotnego do podjęcia pracy }\end{array}$ & $\begin{array}{l}\text { - ustawa o promocji zatrudnienia } \\
\text { i instytucjach rynku pracy nie wskazuje, } \\
\text { jaki musi uptynąc minimalny okres } \\
\text { realizacji IPD, by ponownie można byłoby } \\
\text { ustalić profil pomocy dla bezrobotnego }\end{array}$ \\
\hline & & $\begin{array}{l}\text { - po ponownym ustaleniu profilu } \\
\text { pomocy następuje przygotowanie wraz } \\
\text { z bezrobotnym nowego IPD }\end{array}$ & \\
\hline & & $\begin{array}{l}\text { - PUP, po ustaleniu profilu pomocy, } \\
\text { informuje bezrobotnego, jakimi formami } \\
\text { pomocy może zostać objęty w ramach } \\
\text { ustalonego profilu pomocy }\end{array}$ & $\begin{array}{l}\text { - po profilowaniu bezrobotny zapomina, } \\
\text { w jakim jest profilu pomocy, ale wie, jaka } \\
\text { forma pomocy mu przysługuje }\end{array}$ \\
\hline \multirow[t]{2}{*}{3} & \multirow[t]{2}{*}{$\begin{array}{l}\text { Wyrejestrowanie } \\
\text { się osoby } \\
\text { bezrobotnej } \\
\text { z rejestru osób } \\
\text { bezrobotnych }\end{array}$} & $\begin{array}{l}\text { - osoba bezrobotna składa we właściwym } \\
\text { dla swojego miejsca zameldowania PuP } \\
\text { oświadczenie o wyrejestrowaniu sie, } \\
\text { podając jego przyczynę, np. podjęcie } \\
\text { pracy }\end{array}$ & $\begin{array}{l}\text { - wyrejestrowanie może być nadużywane } \\
\text { w celu zmiany przez bezrobotnego profilu } \\
\text { pomocy }\end{array}$ \\
\hline & & $\begin{array}{l}\text { - ulega zmianie statystyka osób } \\
\text { bezrobotnych prowadzona przez PuP }\end{array}$ & $\begin{array}{l}\text { - urzędnik PUP nie ma wpływu na liczbę } \\
\text { rejestracji i wyrejestrowania się } \\
\text { bezrobotnego }\end{array}$ \\
\hline
\end{tabular}

Źródło: Opracowanie własne na podstawie przepisów prawa oraz informacji uzyskanych podczas wywiadu pogłębionego przeprowadzonego wśród pracowników trzech powiatowych urzędów pracy na terenie województwa łódzkiego w maju i czerwcu $2015 \mathrm{r}$.

Ponad roczny okres funkcjonowania profilowania pomocy dla bezrobotnych ukazał nam zalety i wady tej procedury. Warto jej przyjrzeć się bliżej, by poprawić obecnie funkcjonujący system pomocy dla bezrobotnych oraz znaleźć dodatkowe środki w budżecie państwa na umożliwienie bezrobotnym korzystania $\mathrm{z}$ różnych form pomocy, która im przysługuje w ramach danego profilu. Należałoby się również zastanowić, czy funkcjonujące trzy profile pomocy dla bezrobotnych są wystarczające, czy też należy zwiększyć ich liczbę. 


\section{Podsumowanie}

Bezrobocie jest bez wątpienia problemem społeczno-gospodarczym XXIw. i dotyczy wielu krajów, w tym także Unii Europejskiej. W Polsce stopa bezrobocia rejestrowanego w końcu września 2015 r. kształtowała się na poziomie 8,7\% ludności aktywnej zawodowo. Największy udział bezrobotnych odnotowano wśród osób długotrwale bezrobotnych, osób do 30 roku życia oraz bezrobotnych około 50 roku życia ${ }^{37}$. Wielu z nich albo pracuje na czarno, albo wybiera pracę za granicą. Widoczne jest to szczególnie w powiatach rolniczych, gdzie osoby bezrobotne nie mają perspektyw na znalezienie pracy, a dodatkowo mają problemy z dojazdem do niej. Potwierdzają to wyniki badań Narodowego Banku Polskiego wśród osób bezrobotnych.

Czy w związku z trudną sytuacją na rynku pracy obecne profilowanie pomocy pomoże bezrobotnym znaleźć pracę? Celem profilowania jest uchwycenie wśród osób bezrobotnych tych, którzy rzeczywiście poszukują i chcą podjąć pracę. Ten sposób pomaga lepiej oszacować bezrobocie, które obecnie jest w Polsce. Jednak sama statystyka bezrobocia nie wyjaśnia wszystkiego, ponieważ potrzebna jest pomoc w ramach danego profilu, na którą w chwili obecnej, jak mówią sami urzędnicy powiatowych urzędów pracy, nie ma funduszy.

Niewątpliwie najprostszym rozwiązaniem problemu bezrobocia byłoby tworzenie nowych miejsc pracy dla osób jej poszukujących, a z drugiej strony dofinansowanie powiatowych urzędów pracy na rzecz wsparcia różnych form pomocy dla bezrobotnych. Nie ulega także wątpliwości, że potrzebne jest wsparcie zatrudniających przez państwo, aby ci chętniej zatrudniali osoby chcące podjąć pracę. Należy zachęcić nowych inwestorów, dzięki którym mogłyby powstać nowe miejsca pracy. Jednocześnie trzeba zwrócić uwagę na odpowiednie kształcenie młodzieży oraz przekwalifikowanie się osób bezrobotnych oraz monitorować zawody, na które jest $\mathrm{w}$ danym okresie zapotrzebowanie.

\section{Literatura}

Kabaj M., Program przeciwdziałania ubóstwu i bezrobociu, IPiSS, Warszawa 2000. Kryńska E., Dylematy polskiego rynku pracy, IPiSS, Warszawa 2001.

37 MPiPS, Departament Rynku Pracy, Raport miesięczny - październik 2015 r., Bezrobocie rejestrowane w Polsce, s. 3. 
Kwiatkowski E., Bezrobocie, Podstawy teoretyczne, Wydawnictwo Naukowe PWN, Warszawa 2002.

Męcina J., Niewykorzystane zasoby. Nowa polityka rynku prac, IPS UW, Oficyna Wydawnicza ASPRA-JR, Warszawa 2013.

Mlonek K., Bezrobocie w Polsce w XX wieku w świetle badań, Wydawnictwo i Zakład Poligrafii Instytutu Technologii Eksploatacji, Warszawa 1999.

Raport miesięczny MPiPS, Departament Rynku Pracy, Bezrobocie rejestrowane w Polsce, październik $2015 \mathrm{r}$.

Raport NBP z 2013, Badanie ankietowe rynku pracy, Narodowy Bank Polski, Warszawa 2013.

Rozporządzenie Ministra Pracy i Polityki Społecznej z dnia 12 listopada 2012 r. w sprawie rejestracji bezrobotnych i poszukujących pracy, DzU 2012, poz. 1299.

Ślebarska K., Postawa wobec pracy jako predykator dażenia do zatrudnienia, w: Człowiek - praca - organizacja. Wymiary socjologiczne, psychologiczne i zarzadcze, Wydawnictwo PCz, Częstochowa 2010.

Ustawa z dnia 20 kwietnia 2004 r. o promocji zatrudnienia i instytucjach rynku pracy, DzU 2004 nr 99, poz. 1001.

Ustawa z dnia 29 sierpnia 1997 r. o Narodowym Banku Polskim, DzU 2013, poz. 908 z późn. zm.

Wojdyło-Presner M., Profilowanie bezrobotnych jako metoda przeciwdziałania dlugookresowemu bezrobociu, Wydawnictwo Naukowe UMK, Toruń 2009.

\section{The Unemployed - Profiling Problems and Challenges}

The aim of this article is to present how aid is offered to the unemployed and how it is registered in Poland. Special attention is given to profiling as the new kind of aid offered. The procedure was introduced elsewhere already in the $1990 \mathrm{~s}$ whereas in Poland it has been in use for two years now. The paper is based on the official statistics provided by the Ministry of Labour and Social Policy and the National Bank of Poland, and interviews with civil servants working with the unemployed. The analysis points to the need for diversification of the kinds of profiling aid for the unemployed.

Keywords: labour market, unemployment, profiling aid, registration of the unemployed 


\section{L'enregistrement des chômeurs et les formes d'assistance}

Cet article vise à montrer comment les chômeurs s'inscrivent comme demandeurs d'emploi auprès de Pôle emploi en Pologne et quelles sont les formes d'assistance pour les chômeurs. Une attention particulière est accordée à un nouveau type d'aide - le profilage. Cette procédure a déjà été connue dans les années 90 à l'étranger. Dans l'article, l'auteur utilise des données statistiques du Ministère de l'emploi et de la politique sociale et de la Banque nationale de Pologne ainsi que les résultats de ses propres recherches (interviews). L'analyse démontre la nécessité de développer le profilage des chômeurs.

Mots-clés: le marché du travail, le chômage, le profilage, l'enregistrement des chômeurs

\section{Регистрация и формы помощи безработным}

Целью статьи является показать, как проводится регистрация безработных в Польше и какую помощь им предоставляется. Особое внимание уделяется новому типу поддержки безработных - профилированию. Хотя эта процедура используется в других странах уже с девяностых годов, в Польше она была принята два года назад. В литературе отсутствует тема профилирования безработных в Польше. Настоящая статья пытается восполнить недостаток знаний в этой области. В работе использовались статистические данные из ежемесячных отчетов Министерства труда и социальной политики за 2015 год, относящиеся к уровню безработицы, включая процентное соотношение по профилям помощи, а также исследования, проведенные Национальным банком Польши среди безработных. Кроме того, автор провел собственное, инновационное исследование (углубленное интервью) среди 39 респондентов - чиновников местных управлений труда (Urzad pracy) в лодзинском воеводстве, которые каждый день имеют дело с профилированием безработных. Это исследование позволило выявить положительные и отрицательные стороны профилирования безработных. Анализ материала показал необходимость рассмотрения вопроса об увеличении количества типов профилей помощи безработным.

Ключевые слова: рынок труда, безработица, профилирование помощи, регистрация безработных 